Title:

Displacing xeno-racism: The discursive legitimation of native supremacy through everyday accounts of 'urban insecurity'

By

\author{
Andrés Di Masso ${ }^{1}$ (first author ${ }^{2}$ ) \\ Angela Castrechini ${ }^{1}$ \\ Sergi Valera ${ }^{1}$
}

${ }^{1}$ PsicoSAO Research Group, Social Psychology Department, University of Barcelona

${ }^{2}$ Institutional/personal address: Pg. Vall d'Hebron, 171, 08035 Barcelona (Spain) (also for proofs and offprints)

Email address: $\underline{\text { adimasso@ub.edu }}$

Telephone: +34933125179

Short title/Running head: Displacing xeno-racism

File size: $162 \mathrm{k}$

Words: 8.376 (article without references), 9.575 (article with notes and references) 


\section{Autobiographical notes:}

Andrés Di Masso, $\mathrm{PhD}$, is lecturer in social psychology, political psychology and qualitative methods at the University of Barcelona. His research focuses on the discursive construction of people-place relations, with a specific interest in its ideological implications for the regulation of subjectivities and social life in public spaces. His work includes the exploration of citizenship construction as a locational practice, as well as the role of place-rhetoric in the reproduction of xenophobia and nationalism.

Angela Castrechini, $\mathrm{PhD}$, is lecturer in social psychology, communication psychology and environmental psychology at the University of Barcelona. Her research focuses on social representation theory and on visual and media communication processes. Her work includes the exploration of social representations of environmental problems and the role of mass media in the construction of environmental and social issues.

Sergi Valera, $\mathrm{PhD}$, is senior lecturer in applied social psychology and environmental psychology at the University of Barcelona. He investigates the construction of personal and social identity derived from people-place relations and their consequences on both social and subjective well-being and social life in public spaces. His work includes the exploration of fear of crime and perceived insecurity in the city, and the role of place-identity and urban social identity as dimensions of a positive environmental psychology. 


\title{
Displacing xeno-racism: The discursive legitimation of native supremacy through everyday accounts of 'urban insecurity'
}

\begin{abstract}
Socio-cultural approaches to fear of crime have suggested that responses to questionnaires may channel broader social attitudes towards other culturally-related topics also shaping the public meaning of 'crime', such as immigration. Building on this idea, this article uses a discourse analytic framework to examine how xeno-racist ideas, claims and positions are metonymically worked through everyday opinions about 'urban insecurity' as a crimerelated construct. The analysis of open-ended interviews to ordinary citizens in Barcelona shows that the position of a 'threatening Other', typically afforded by the insecurity narrative, is pervasively constructed in xeno-racial terms -whether explicitly or by implication-, but is rhetorically rejected on the narrative grounds of its alleged criminal acts. This xeno-racial version of the criminalised Other is itself managed in interaction as a sensitive topic through a set of deracialization strategies that displace rejection from the language of immigration towards culturally contiguous languages of incivilities, cultural differences and socioeconomic disadvantage. The article deepens in the ideological versatility of discourses that subtly warrant the structural privilege of 'natives' vis-à-vis ‘immigrants', thereby legitimizing a tenacious system of native supremacy.
\end{abstract}


Key words: xeno-racism, metonymy, fear of crime, urban insecurity, native supremacy 


\section{Introduction}

Fear of crime discourse has proliferated in the social, political and academic agendas during the last decades in both American and European cities (Lee, 2007). In Spain, fear of crime has reached the public sphere in the form of 'urban insecurity', featuring a series of emotions and ideas subjectively related to actual or imaginary risks of victimization affecting any person, and particularly vulnerable social groups, in the urban open space.

Surprisingly, however, survey-based reports persistently show that perceived urban insecurity tends not to parallel objective risks of victimization, leading scholars and policymakers to the conclusion that other sorts of factors might be involved in the social construction of fear (e.g. Carro, Valera and Vidal, 2010; Miceli, Roccato and Rosato, 2004; Van Dijk, 1992a). Taking this argument further, a particular strand of socio-cultural approaches convincingly suggests that talk about fear of crime may not even deal much with subjective fear of victimization, but may rather serve to channel broader social attitudes towards other culturally-related topics also shaping the public meaning of 'crime'. As Jackson (2004: 962) puts it, 'crime acts as a lightning rod -a metaphor for social problems in the local community and to wider society'. Accordingly, opinions about crime become at the same time opinions about sensitive issues beyond crime that, for some reason, may not be easy to account for outside the crime-frame. 
This setting opens up the chance of exploring how and why these other "backstage" issues and related attitudes are discursively navigated and worked through crime-embedded accounts of fear and insecurity. One of the most prominent debates culturally nested in the fear of crime discourse is that of immigration and racial minorities, entailing that often prejudiced positions against immigrants are surreptitiously articulated through a language of risk, fear, anxiety and/or hatred towards a delinquent-like other (see Keith, 1993; Sercombe, 1995; Tulloch et al., 1998; Van Dijk, 1984, 1987, 1992a; Van San, 2004). The role of racist stereotypes in shaping both public perceptions of crime and the subjective likelihood of being victimized by ethnic minorities has been extensively researched (e.g. Pickett et al., 2012; Quillian and Pager, 2010; Welch, 2007). This circumstance is particularly salient in the Spanish context, in which public safety and crime are cornerstones of a national debate recurrently tied to xenophobic, assimilationist views of acculturation (Fekete, 2009; Taras, 2012). Ultimately, in this frame talk about insecurity and crime becomes a discursive arena that culturally entitles individuals to mobilize xenoracist appraisals shielded from controversial accusations in the name of a legitimately fearable other (i.e. the delinquent).

Building on these contributions, in this article we examine how xeno-racist ideas, claims and positions are metonymically worked through everyday opinions about 'urban 
insecurity' as a crime-related construct, drawing on discursive data from a qualitative study conducted in the city of Barcelona. In doing so, we deepen into the study of how mundane and apparently innocuous xeno-racist rejection operates through its displacement across culturally contiguous discursive frames with different levels of public acceptance.

\section{Theoretical background}

Xenophobia can be defined as 'fear or dislike of foreigners' (Taras, 2012), frequently translated into 'rejection, hostility and aversion' (Taguieff, 1987). According to these authors, xenophobia is a general form of fear that encompasses racism as a specific, historically situated phenomenon that anchors rejection of the Other in the perception of tangible, bodily properties (e.g. skin-colour, eyes, etc.), otherwise arbitrary. Xenophobia, racism and socio-economic status intersect in the concept of 'xeno-racism' (Sivanandan, 2001), a more nuanced ideology of rejection constructed around the figure of the impoverished stranger, not necessarily "racially" different, but marked by socio-economic disadvantage and other social or cultural signifiers of Alterity (see also Del-Teso-Craviotto, 2009; Fekete, 2009).

The analysis we discuss in this article adopts the perspective of xeno-racism, which allows us bringing into sharper focus those components of xenophobia that 'bear all the 
marks of the old racism' (Sivanandan, 2001) and work ideologically sustaining a broader system of socioeconomic stratification. In order to examine xeno-racist enactments produced in a surrogate discursive frame (i.e. urban insecurity), the analysis is theoretically grounded on three interrelated strands of discursive research on implicit, indirect or nonblatant forms of xeno-racist rejection.

\section{Topic-subsumed ethnic prejudice, denial and deracialization}

A first set of studies stems from Van Dijk's $(1984,1987)$ exhaustive analysis of ethnic prejudice in everyday discourse in Amsterdam and San Diego, CA. Van Dijk identifies a series of recurring topics (i.e. what interviewees are actually 'talking about') that, while portraying ethnic minorities in negative terms, easily divert attention from racialized depictions. Specifically, talk about 'social problems', such as unsafety, criminality or drugs, frequently allows interviewees connecting indirectly, via conversational context and subtle cues, the 'problematic' subject with an un-explicit ethnic minority (Van Dijk, 1984). Likewise, appealing to 'cultural differences', 'economic interests' and 'deviant' practices (e.g. dirtiness, mugging, etc.) also enables the indirect portrayal of the (submerged) foreigner as a threat (Van Dijk, 1987, 1992a). Usually derived from elite discourses, the topic of crime and related arguments implying norm violation typically invoke in the 
surface of the conversation an elusive "Them" which is the object of an underlying ethnic prejudice held by "Us" (Van Dijk, 1992a). Infractions and abnormal actions may appear as narrative 'complications' within the interviewee's account, expressing norm-breach, conflict and moral sanction by the ethnic majority (Van Dijk, 1984). In semantic terms, implications and, in particular, presuppositions (i.e. implicit knowledge and assumptions speakers must share in order to give meaning to what is explicit in the conversation) may be crucial to reject unaccepted forms of difference while avoiding and resisting race-related accusations (Van Dijk, 1992a, 1993).

The latter connects with the discursive denial of racism, including a wide array of strategies (e.g. disclaimer, justification, inversion, etc.) that enable people building negative representations of racialized out-groups while protecting the self from accusations of being a racist (Van Dijk, 1992b). The main point made in this and subsequent studies is that culture not only affords its competent members a series of categories to construct a racial version of the other, but it also provides socially organized forms of using language to perform racism in a less self-compromising way. Augoustinos and Every (2007) have briefly summarised research on denial and have broadened it to encompass two more discursive strategies. One the one hand, as in Van Dijk's work, deracialization (Reeves, 1983) allows portraying minority out-groups in non-racial terms, by eliminating, 
substituting or attenuating racial language (for instance, adopting the discourse of the nation). On the other hand, what they call 'liberal arguments for illiberal ends' capitalize on Wetherell and Potter's (1992) classic study of racism in New Zealand to stress how common liberal tropes connoting a progressive ideological profile (freedom, equality, etc.) may be functional, in their immediate argumentative effects, to justify discriminatory situations and practices. Put shortly, deracialization allows doing race-blind racism, while liberal arguments can be at the service of legitimizing race-phobic views and practices.

\section{Metonymic displacements of rejection}

A second strand of discursive research on non-blatant racism derives from the so-called 'spatial turn' in social psychology, developed particularly by Dixon and Durrheim in their

research program on de-segregation and social change in South-Africa. Interested in everyday discursive practices subtly perpetuating racist ideology after Apartheid, Dixon et al. (1994) analyzed letters to newspapers in the Cape Province showing how resistance to racial contact was articulated through a language of ecological fragility. Whites warranted their rejection to the physical proximity of black people arguing that the environmental consequences of the latter's re-location in a settlement close to whites' dwellings would spoil nature, thereby making whites' racist claims ethically acceptable in the name of 
environmental (not racial) protection. Relatedly, in subsequent analyses the authors showed how whites' aversion to blacks was accounted for using a discourse of place-identity and health-restoring environmental properties. Whites signified de-segregation as a threat to long-standing psychological relationships with "their" (white-owned) spaces, and therefore framed resistance to de-segregation not as a racist reaction but as a culturally normal defense against ineffable bonds with biographically meaningful places (Dixon and Durrheim, 2000, 2004). Likewise, Durrheim and Dixon (2001) and Di Masso (2012) showed how the rhetoric of bad manners in public spaces provided whites and local inhabitants, respectively, a series of discursive entitlements to complain about the presence of unwanted people (blacks, immigrants) in beaches and urban squares, warranting their exclusion in a way that made xeno-racial categories a secondary issue.

Taken together, these studies illustrate one same discursive process consisting on reframing racist rejection using parallel languages that stand for an otherwise explicit xenoracial repertoire. Far beyond discursive denial or justification, the morally self-repairing properties of which are subsidiary of an explicit invocation of race or ethnicity (e.g. "I have nothing against blacks, but..."), in these studies we find a metonymic displacement of rejection. This mechanism entails that xeno-racist aversion and its discriminatory effects are entirely transferred to, expressed through and produced within a discursive frame (e.g. 
ecology) that is figurative with respect to its implicit discourse (e.g. race), so xeno-racial identities almost need not to be drawn on explicitly because they are inferred from the xeno-racist cultural background shared by speaker and hearer -what Durrheim et al. (2008) have called racism "by implication". The displacement of xeno-racist affections from one discursive frame to another has metonymical characteristics insofar as the foreground figurative discourse is semantically contiguous, within the xeno-racist cultural imaginary, to the background racial discourse, so the former can replace the latter to produce the same ideological (racist) effects. The use of metonymy to do racism has been noticed, for instance, by Stewart et al. (2010: 9) in their recent discursive analysis of the construction of the Latino as an 'illegal immigrant', arguing that this narrative allows 'distilling the complex economic, personal and cultural causes and consequences of immigration to the United States (...) into simpler mediated stories and characters'. The 'illegal immigrant' metonymy displays deracialization properties, as the xeno-racist connotation of threat is mitigated by appealing to the crime-related frame of legality. Xeno-racist rejection more elaborately subsumed into figurative languages is found in Santa Ana's (1999) study of the 1994 California Proposition 187 campaign, in which immigrants were transfigured into a "desease" within the metaphor of the nation as a body, and into "dirt to be swept out" following the metaphor of nation as a house. 
Xeno-racism and nativist ideology

A third set of theoretical arguments assumed in this article brings together the concepts of ideology, nativism and legitimation through a geographical metonymy that essencializes the identity of the immigrant as a spatially transgressive presence in "our territory". Extending Wallwork and Dixon's (2004) analysis of the role of landscape-rhetoric in the reproduction of nationalism, the metonymic substitution of the nation-as-people (e.g. "Spaniards") for the nation-as-place (e.g. "here", "our country", etc.) also plays a key role in the ideological workings of xeno-racism. Through the use of locational pro-terms (Schegloff, 1972), such as "here", "from elsewhere", "those who are coming", "go back to", etc., a spatial metonymy replaces national identity with territorial identity (e.g. "people belonging here" or "being from elsewhere"). This substitution constructs "the immigrant" as essentially different from "locals" by simply depicting the former as a literally out-ofplace Alterity, which in turn makes expulsion and deportation its ideologically consequent claims hardly needing to invoke race or ethnicity.

In this context, ideology is less related to the truth status of specific ideas and beliefs stemming from a reality-check, than to how certain discourses and material practices are at the service of exerting some form of domination (Thompson, 1990). As Billig (1991) states, a belief is ideological if it is strategic to support or undermine a 
dominant arrangement of power relations, status and hierarchy sustaining the social order. This sociological view of ideology considers that the relationships between objective interests, social groups and ideological discourse are more loose, nuanced and apparently contradictory than implied by its epistemological definition as a class-distributed state of false consciousness. With this conception in mind, we can consider nativism (Miller, 1994; Stewart et al., 2011) an ideological manifestation of xeno-racism organized around the ordinary belief that natives (i.e. those born-and-bred "here") have more entitlements and ought to have priority vis-à-vis "immigrants" (i.e. those "coming from elsewhere"), especially whenever allocation of resources is at stake (e.g. rights, jobs, public services, salaries, territory, etc.). Crucially, then, nativism operates ideologically by mobilizing a locational metonymy of xeno-racism psychologically grounded on the common-sense idea that people authentically belong in a place (and not in another). This culturally rooted assumption ultimately serves to justify the privilege of the in-place in-group ("natives") and the subalternity of the out-of-place out-group ("immigrants") in the social structure. Accordingly, we refer to this state of structural privilege as native supremacy, and define legitimation as the set of institutional and daily practices supporting this state of supremacy as something just, socially acceptable and even desirable (Thompson, 1990; Wetherell and Potter, 1992). 


\section{Research context and Method}

\section{Context}

As we stated earlier, in Spain debates about crime and public safety typically convey cultural fears towards immigrants mounted on a less evident xenophobic rationale. The association between delinquency and immigration in the public opinion, supported by an already significant $43 \%$ of the Spanish population back in 1991, raised to $69 \%$ in 2002 according to the barometer of the national Centre for Sociological Investigation, coinciding with an eight-point demographic raise of foreign population. The role of the right-wing government and elite-aligned mass media was crucial in this increased criminalization of the immigrant, a period in which the minister of Home Affairs (Mariano Rajoy, current Prime Minister) repeatedly relied on rhetorically designed statistic data on incarceration to sustain that criminals and delinquents were mainly foreigners (Colectivo IOÉ, 2005). This situation has been recently aggravated by the global financial crisis. According to the

official report of the International Organization for Migration in 2012, the segment of Spanish citizens overtly expressing xenophobic attitudes towards immigrants has reached $37 \%$ (compared to $10 \%$ in year 2000), added to $30 \%$ of ambivalent opinions and featuring $73 \%$ of Spaniards supporting expulsion of immigrants with imputed criminal charges in 2010. In Barcelona, the Local Security Plan 2012-2015 currently stresses how crisis-related 
anxieties and uncertainties have reinforced the stereotype of the immigrant as a delinquent, while simultaneously reporting once again that the perception of insecurity does not mirror objective rates of victimization. In this context, we conducted a qualitative study of everyday opinions about urban insecurity in Barcelona ${ }^{1}$.

\section{Aims and data}

The aims of the study were to explore how ordinary citizens construct and negotiate the meaning of 'urban insecurity' when asked in a daily setting (the street), and to analyse the ideological implications of their accounts of insecurity as a matter of social order and control. The corpus of discursive data was gathered through 82 open-ended interviews between October 2011 and March 2012 in the streets of four neighbourhoods with high (Raval, Casc Antic) and low (Les Corts, Sarrià) objective rates of victimization, in order to grasp possible gaps between discourse and actual delinquency. Raval and Casc Antic are also densely populated downtown neighbourhoods with high rates of low-income population and immigrant inhabitants. Interviews included four main questions: 1) People are currently talking about urban insecurity, what do you think about this? 2) Do you feel unsafe in Barcelona? 3) Why is there urban insecurity (if there is) in Barcelona? And 4) What measures do you think should be promoted to face insecurity? No social categories 
were made explicit in the questions to avoid priming stereotypes. Respondents were randomly selected by the interviewer in the street with the only guidelines of choosing both men and women of all ages, as well as having testimonies of immigrants also. However, for the purposes of this article, we only include in the analysis extracts from the 67 interviews to non-immigrant citizens.

\section{Analytic framework}

Interviews were transcribed verbatim using no specific conventions other that '(.)' to indicate a small pause, '((comment))' to insert transcriber's contextual information (see Jefferson, 1984) and '(...)' to signal that analytically not relevant text is being omitted. The analytic approach was informed by the main principles of discursive social psychology, interested in fact construction (i.e. depicting realities as objective-seeming), social action (e.g. blaming, excluding, dodging responsibilities, etc.), variability (i.e. function-driven discursive shifts) and rhetoric (i.e. explicit or implicit persuasive orientation towards alternative possible accounts) (Edwards and Potter, 1992; Potter and Wetherell, 1987). We assumed Wetherell's (1998) suggestion of focusing both on the fine-grain details of talk (e.g. turn-taking, word-choice, repetition, etc.) and on the broader cultural patterns and ideological streams reproduced and navigated through talk. In the initial steps of the 
analysis we reconstructed a central common narrative (Van Dijk, 1984) in most interviews, shaping a coherent story of delinquency in which insecurity is caused by someone victimizing another person, in a context in which a third party (usually the police, other neighbours and/or the local administration) somehow intervenes (or not). In a later stage of the analysis, we looked for the most relevant topics and narrative categories (Van Dijk, 1987) within this story-line of crime that could reinforce the discursive-psychological interpretation. We then focused on the discursive construction of the identity allegedly causing insecurity (the 'fear-able Other', Lee, 2007) and tracked its metonymic formulations across foreground and background discourses (Durrheim et al., 2008), spotting in particular geo-spatial metonymies expressed via locational pro-terms (Schegloff, 1972) and finally pinpointing semantic implications and presuppositions (Van Dijk, 1993). These last analytical moves allowed revealing the submerged presence of a xeno-racial Other whose denigration and discrimination crucially surfaced in specific moments of the interviews. We selected for the analysis section those extracts representing the most common accounting patterns, which typically combined geospatial metonymies, deviant actions, cultural specificities and socioeconomic disadvantage standing for the identity of “the immigrant", frequently leading to a narrative 'conclusion' of territorial control or expulsion of the (immigrant) delinquent. 


\section{Analysis}

\section{'Cleaning-up the house'}

Across the interviews, the most recurring topic drawn on to construct a credible version of urban insecurity was the existence of a criminal identity whose removal from the public space would ensure a return to normality. The discursive construction of this identity ranged from explicit xeno-racialization to more deracialized accounts finally foregrounding xeno-racial appraisals:

(1) Well, there is insecurity, to be sure. There's a lot of (.) at least what I see around here, lots of Muslims passing (.) Moors or call them however you want, who always have their hands inside others' pockets. And you can see them, huh?! (...) many more are here than should have come, that's for sure. Because we already had thieves and we just needed more of them. But besides that, it's like everything has come in, and I say everything and not everyone, but everything. And of course, if there hasn't been a bit of cleaning-up (.) the good has come but the bad has come here massively, which is the first that leaves a country. (Woman, 55, Raval)

(2) ... A man that you could see that wasn't normal, stopped me and made me silly questions, huh? (...) There's an infinity of things promoting (.) promoting that strange people come here and have come only for this, to harm, this is my opinion (...) Because there are neighbourhoods down-town that, if there, there it is, it's the non plus ultra, that, of people, of bad people, huh? (...) Look, I think that the most important measure would be controlling the borders (.) controlling, I think they don't do it, 
because everybody comes here and is here without (.) without being legalized (...) everybody comes here, brazenly, huh?, brazenly, mainly strangers, strangers. (Man, 80, Les Corts)

(3) Interviewee: I personally do ((feel safe)), but I see old people who don't feel safe. They have things snatched and stuff (.) they are cruel to the weakest people (...)

Interviewer: What could be done to help with this regard?

Interviewee: More police, expelling people who commit misdemeanors and don't have papers (Man, 50, Raval)

In extracts 1 to 3 interviewees give their opinions about urban insecurity producing a common account of blame that specifically spots a same group of people who are made responsible for creating urban insecurity. This is discursively accomplished in different ways, albeit the three accounts lead to the same conclusion that it is the presence of these people, and not their alleged criminal acts, what is abnormal and should be avoided. Hence, at the beginning of extract 1 there is an explicit mobilization of xeno-racial categories ("Muslims", "Moors") that are depicted as the main perpetrators of delinquency (“... have their hands inside others' pockets”). This initial 'summary' (Van Dijk, 1984) goes on presenting ethnic-related delinquency as an objective fact by using extrematizations ("lots of Muslims", “always have their hands...") (Potter, 1996) and voice-warranting devices ("at least what I see...", “and you can see them, huh?") (Gergen, 
1989). Having depicted the criminal identity in xeno-racial terms, the interviewee then moves towards making a general claim against these people in a way that replaces the rationale of criminality with a broader argumentation about the (in)admissible degree of presence of foreigners ("many more are here than should have come") and uses dehumanization language to despise them ("everything has come in, and I say everything and not everyone"). The transgressive connotation in this account operates, on the one hand, through the idea of an excess of foreigners, which capitalizes on the xeno-nationalist assumption that countries are like "containers" with limits to foreign presences (CharterisBlack, 2006). On the other hand, the norm-breaching aspect in the interviewee's claim works through the locational metonymy of the foreigner-criminal as being out of place ("many more are here than should have come", "the bad has come here massively"). This locational metonymy is itself embedded in the metaphor of the country as our house (Santa Ana, 1999), defining foreigners as "dirt" that must be removed from home ("if there hasn't been a bit of cleaning-up..."). This last discursive move, together with the container argument of excess, makes a clear plea for control and territorial exclusion of foreigners. In sum, the account initially enshrines rejection in the discursive frame of insecurity to finally warrant a general xeno-racist hostility towards "the bad" immigrant whose presence "here" 
is not welcome, a claim that finds an argumentative closure in the stereotypical 'topos' (Van Dijk, 1984) according to which "they are the first to leave a country".

The cleaning-up the house argument appears in extract 2 in the more prosaic form of "controlling the borders". In this account, the xeno-racial categories implied by the discourse of borders are initially deracialized as "strange people" and "bad people coming to harm", thus indicating stereotypical weirdness and threat (Van Dijk, 1987), to be finally overtly presented as "people coming here without being legalized" and "strangers". Again, the question for insecurity triggers anti-immigration discourse as the account moves from an implicit xeno-racial subject to a more explicit formulation. One must note here that, compared to extract 1 , the depiction of the foreigner lacks nationality as well as markers of ethnicity. Also, delinquency does not feature as a relevant issue but is rather replaced by references to deviant characters ("a man that wasn't normal"), abnormal behaviour ("making silly questions") and a moral language of "bad people" with deliberately threatening intentions ("coming to harm", "brazenly, brazenly"). This discourse certainly displays more sensitivity towards the self-compromising possibility of making xeno-racist claims (Van Dijk, 1992b). However, caution immediately collapses in face of border control and legal entrance ("people coming here without being legalized"), one of nativist ideology's maximum expression. As in extract 1 , insecurity paves the way for mobilizing 
xeno-racist prejudices. Moreover, the racial connotation of the interviewee's appraisals in extract 2 relies on a spatial metonymy ("there are neighbourhoods down-town..."), meaning those places in Barcelona with precisely higher rates of immigrants. This substitution of people for location is particularly relevant here since the interview takes place in a different neighbourhood (Les Corts). By transporting his account to the geographical context of "down-town", the interviewee is able to articulate his allusion to the immigrant in a more concealed manner, counting on the interviewer's background knowledge about the sociodemographic composition of that part of the city. Xeno-racist prejudice circulates at this point by semantic implication (Van Dijk, 1993) through the backstage of the conversation (Durrheim et al., 2008).

This last remark about space-related discourse directly applies to extract 3, in which nativist ideology manifests in a clear-cut manner. In this brief account, the interviewee reports not feeling unsafe, but he then invokes "the old people" who are robbed ("snatched"). The elderly are a vulnerable subject position ("the weakest") typical in the canonical fear of crime narrative (Hollway and Jefferson, 2000) that entitles the speaker to talk about insecurity even if he is not speaking for himself, what Goffman (1981) refers to as "footing". This allows the speaker dodging authorship for what is going to be told, and thus avoiding subsequent accountability. When asked about the measures needed to cope 
with such defencelessness, the interviewee (already self-protected as he is speaking on behalf of the elderly) calls for “expelling people who commit misdemeanors and don't have papers". The 'illegal immigrant' metonymy (Stewart et al., 2010) bursts here into the scene as a criminalizing device at the service of reinforcing the naturalized privilege of natives to determine who is an inadmissible presence in "our" territory. In narrative terms, insecurity appears as currently lacking a proper 'resolution' (something common in prejudiced accounts about minorities), leading to the 'conclusion' that appropriate official actions against the threatening subject should be undertaken (i.e. expelling immigrants) (Van Dijk, 1984).

What is rhetorically relevant here is that this account, as extracts 1 and 2 before, do not display claims of formal control strictly related to the actions provoking insecurity (e.g. sanctions, detentions, community work, incarceration, etc., for pick-pocketing or snatching), but rather act socially as a general rejection of the identity and the very presence "here" of its alleged perpetrators. Delinquency seems not to be the point, but rather "cleaning-up" the country, controlling the borders and expelling those who "misbehave". The force of xeno-racist nativism lies in the deeply self-assumed right of the interviewees to decide who can and cannot be in the country, by virtue of an unquestioned territorial privilege of those who belong in the place. This nativist demand finds a channel for 
expression through the insecurity frame set by the interviewer, so the ideas that "those coming here" rob, do "bad things" and scare the elderly become figurative rhetorical resources ideologically functional within a general xeno-racist argument. Put the other way around, for native delinquents, even though their criminal actions were the same, expulsion is never a chance. In all cases, the question for urban insecurity acts as a cue to warrant natives' preordained right to exclude immigrants following a place-indexical (us-here, them-elsewhere) principle of social order.

\section{Vandalism and incivilities}

Nativist assumptions and related claims for xeno-racist exclusion were also worked through discourses foregrounding different sorts of incivilities and trouble in the open space, implying the breach of socio-spatial norms and connoting a certain degree of urban anomy:

(4) Here ((security)) is disastrous. Even more in this sector. It's disastrous. Fights, they piss everywhere, they rob you if they can (.) whatever you like. Then the disco here, they come out at six in the morning, huh?, and no one can walk through, and police does nothing (...) And dirt, it's dirty, they come out here and piss everywhere, they throw (...) there was also a sector of people that snatched your necklace, mine was snatched in September in Sant Pablo street (...) A girl took it from me (.) I saw another one a person that was black, maybe it's that. (Woman, 59, Raval) 
(5) Yes, there's a lot of insecurity and I won't say that the police doesn't do anything. They sell drugs right here. There are robberies all the time, all the time trouble, always brawl (...) this is always filthy, the people, the people that have brought us here, this is a ghetto, people that have come, it may be their culture, or whatever, they are used to throw what they don't need. They don't throw rubbish inside, they throw it outside, but this is nonsense, but lots of nonsense makes a huge one, and the neighbourhood is a shit. (Man, 45, Raval)

(6) Interviewee: My opinion ((about urban insecurity))? Well, there's a lot of vandalism. Vandalism, I mean I work in ((gas company)) and I have to visit homes and people are shit-scared (...) The district here is terrible (...) I flip with the faces of people even immigrants, "cause the people that live here, that belong here lifelong, are very scared, very, very, very, you can see it. The elderly are defenceless.

Interviewer: Finally, what kind of measures do you think that...

Interviewee: Well, the one who doesn't have papers goes home, it's as simple as this (.) A superheavy raid here and let it blow out, blow out, but this has to be cleaned-up, I mean, this can't stay like this, and it'll be worse (.) more crisis, more vandalism. (Man, 35, Raval)

A first analytical remark in extract 4 is that the interviewee accounts for the lack of security by using an expectable repertoire of dangerous and criminal activity ("fights", "they rob you if you can", "people that snatched your necklace") entangled with a less directly related discourse of bad manners in public. Although not being criminal actions strictly speaking, 
"dirt" and people that "piss everywhere" and "throw" things are generally considered as morally improper situations in the city's public space. Furthermore, "people coming out the disco at six in the morning" depicts those people as ethically transgressing a temporal norm of civility defining the proper moments for having night fun (certainly not as late as the morning after) and implying other likely annoyances (e.g. making noise when coming out and people are still sleeping). This time-related transgression (Di Masso, 2007; Taylor and Wetherell, 1999) is rhetorically related to the impediment of the universal civic right to freely use the street, implying behavioral-spatial impropriety ("no one can walk through") (Dixon, Levine and McAuley, 2006). Altogether constructs an anomalous situation that portrays their protagonists as trouble-makers. Most importantly, the fact that these arguments are initially entwined with delinquent practices makes the immoral character of reported incivilities more serious and censurable. And conversely, the discursive deployment of the rhetoric of bad manners sets a frame that entitles the interviewee to intensify her complaints against trouble-makers. This discursive amplification of blame is accomplished, on the one hand, through a 'vivid experience' (Edwards and Potter, 1992) of personal victimization, making the situation more real-seeming ("mine was snatched in September in San Pablo Street") and working in the narrative as a 'complication' within a 'setting' in which a vague "they" appears as the troubling Other (Van Dijk, 1984). On the 
other hand, the final reference to a "black" perpetrator works in the account as an argumentative closure ("maybe it's that") that qualifies "them", as if race were the ultimate explanation to crime, incivilities and insecurity mixed in an un-differentiated state of abnormality, a conclusion that is left to the hearer to infer as a logic implication (Van Dijk, 1993) from the shared background narrative of the (black, criminal) immigrant.

This same narrative of deviance implying that minorities cause troubles of all kinds (Van Dijk, 1984, 1992a) appears in extract 5, in which incivilities ("filthy", "brawl", "throwing what they don't need", "rubbish") are also enmeshed with criminal activity ("robberies", "selling drugs"). However, unlike extract 4, these activities are imputed to a subject that is xeno-racially depicted through the metonymic formulations of the "ghetto" and of cultural differences. The ghetto as a self-enclosed area where ethnically different people inhabit discursively replaces the actual people living in it, who are then locationally constructed as "people who have brought us here". This designation only makes sense if the interviewee is already discursively positioned "here", a geographical metonymy translating national belonging into territorial priority. That the interviewee is actually talking about immigrants is then clear, but this us-them border is yet strengthened by using a language of cultural habits ("it may be their culture", "they are used to throw what they don't need"), making disruption of local life "here" a matter of the out-group's essence and consequently 
building the identity of the immigrant as structurally disturbing because of its cultural singularities (see Van Dijk, 1987).

This disruptive presence of immigrants is finally synthesized in extract 6 through an account of vandalism. Even if one does not know exactly the specific activities that fall under this label, the depiction of people as "shit-scared" and "very, very, very scared" frames the situation as quite alarming. In this context, however, threat is unevenly distributed, affecting "people that live here, that belong here lifelong", which unambiguously leaves more or less settled foreigners in the position of the threatening Other. Again, residing in the place means belonging in the local community, but not only that: genuine membership entails having lived "here" the entire life and mainly being born in the place (“... belong here lifelong”). As some scholars have noticed (Marzorati, 2011; Taylor, 2005; Wetherell and Potter, 1992), time and temporal order (e.g. "We were here before") are rhetorically useful devices to construct the authenticity of one's identity as a resident vis-à-vis the unauthentic Other, in this case natives' identity compared to the immigrant. This reference in extract 6 discursively entitles the interviewee to explicitly demand the removal of immigrants "who don't have papers" making them "go home", the place in the nativist imaginary where they authentically belong. The 'illegal immigrant' criminalizing metonymy acts again as a warrant to justify expulsion (using the cleaning-up 
metaphor), however re-framed at the end in a more deracialized way as a matter of vandalism and socioeconomic contingencies ("More crisis, more vandalism"). As in extracts 1 to 5 before, this demand of expulsion (i.e. the narrative 'conclusion') is rooted in an already assumed commonsense belief of native superiority tied to the authenticity of place-identity, mounted on the generalization of the immigrant's identity as a criminal (note that it is never questioned that immigrants, and all immigrants in general -via sinecdoqueare responsible for urban insecurity).

\section{Cultural diversity and socioeconomic disadvantage}

Back in extract 5 we underlined the discursive construction of improper behaviour in public, such as "throwing things" in the street, as a cultural characteristic of immigrants, metonymically reformulated as the "ghetto". Extending this line of argumentation, another common pattern of talk across the interviews foregrounded cultural issues as something essentially related to urban insecurity:

(7) Barcelona is very complex, in terms of multiculturalism, then I think that this complexity you have to (.) you have to manage it more actively (...) to start with, different cultures and religions in Barcelona must be respected, you have 167 languages, minimum, then this already creates complexity in such a compact space like Barcelona's, then I think that it creates conflicts, of course 
it creates conflicts, because people have different ways of living in a space and, well, at one point doors were open to these people and now, well, I think that it's a part of Barcelona's reality (...) By the moment I haven't been robbed and haven't had any problem, then, and I like this diversity, there are people that see it as insecurity (Man, 28, Raval)

The interviewee in this extract is responding to the question about the reasons why he believes that there is insecurity in Barcelona. "Multiculturalism" is immediately brought to the fore as an 'explicative' narrative device (Van Dijk, 1984), implying that the two phenomena are casually related. More interestingly, the opinion given about cultural diversity is argumentatively navigated between two opposite ideas. On the one hand, cultural diversity is depicted as something positive ("different cultures and religions must be respected", "I like this diversity"), allowing the interviewee building a liberal profile based on the multiculturalist assumption of celebration and respect of cultural differences. On the other hand, multiculturalism is also problematic because it creates "complexity" and "conflict", an idea that locates the interviewee in the contrary position of accepting that difference is also controversial. In rhetorical terms, the interviewee is reflexively navigating the 'ideological dilemma' (Billig et al., 1988) of multiculturalism, which revolves around the pros and cons of cultural diversity. This dilemma is decanted when the interviewee relates conflict to the fact that "doors were open to these people", bringing the arrival of 
immigrants into the account and thereby evidencing that earlier "multiculturalism" was standing for immigration. Furthermore, the fact that immediately the interviewee states that "by the moment I haven't been robbed" explicitly links "these people" with delinquency. Even if one accepts that probably the person was precisely trying to deconstruct this link by reporting an experience of lack of victimization, unfortunately the account works ideologically in the opposite way, underpinning the dominant cultural representation that criminalizes the immigrant. Quite ironically, this is made explicit by the same interviewee at the end, when he states that "I like diversity, some people see it as insecurity". From a rhetorical perspective, the point here is not so much if the person is being truly honest, but rather that xeno-racial assumptions are circulating through his most likely good intentions. Even if the speaker does not share the perception that immigration equals insecurity, he is in fact drawing on the "multicultural" metonymy of the immigrant, and on the possibility of being robbed by him, precisely to account for the general question about insecurity. 'Vivid ideologies' are contradictory and their value does not reside in the agent's intentions, but in their implications for the naturalization and reproduction of views sustaining prejudiced social relations (Billig, 1991).

This comment supports Taguieff's (1987) so-called antinomy of racism, according to which racist rejection is also performed through heterophilic expressions featuring the 
promotion of cultural diversity. This paradoxical manifestation of racism also reifies "them" as essentially different from "us", within a broader politics of identity that entitles natives to define what is positively different about the Other and thereby trace the normative boundaries of cultural distance, proximity and acceptance.

That 'cultural differences' are common-place substitutions of 'immigrants' in xenophobic discourse has been highlighted by Van Dijk (1984, 1992a) and Gotsbachner (2001). In both cases, social and economic weaknesses are also found to be equally relevant as a semantic field in discourses about foreigners. Extracts 8 and 9 allow taking a closer glance at this issue:

(8) We are not safe (...) there's really no justice at all, everything, families, people (.) that are unemployed, people don't have a job (...) you find that you are unemployed, that (.) that you're bad, that you have a mortgage that you can’t pay and that, I mean, everything influences everything (...) I'm not against anyone, do you understand me? The one who's here, be welcome and, I don't know how to explain it, I think it's ok, but what I don't see it's fine is that if we are already two thousand inhabitants here, there can't be four, four thousand inhabitants when it can't be. It should be limited, limited (.) for me it would consist on limiting and saying "well, we are these people here, we are the people who stay", and that's it. (Woman, 60, Raval) 
(9) Interviewee 1: Yes, I don't know, it would be easier to give these people opportunities so they don't need to...

Interviewee 2: Raising awareness is slower than dictating what must be done, isn't it? It's slower and it requires a movement of the people for, of the people and understand (.) assume, assume that immigration is increasing and can't be avoided, it can't be avoided...

Interviewee 1: And that we have to cohabit, and if these people are given a chance, if they are given jobs then they won't have the need, probably, of committing misdemeanors, I guess more policies like this should be promoted...

Interviewee 2: Awareness, awareness...

Interviewee 1: Giving them opportunities and not censuring via police (Men, 30, Casc Antic)

Unlike most of the interviews, urban insecurity is not depicted in extract 8 as something related to criminal activities, but as a more fundamental helplessness derived from an economic crisis hosted in the contextual background of the conversation ("no justice", "people are unemployed", “don’t have jobs", “mortgages you can’t pay"). This sets the scene to initiate an argumentative sequence involving a set of people whose identification is geographically relevant ("the one who's here...") and positioning the speaker (both spatially and morally) as someone entitled to evaluate the propriety of their presence (“... be welcome"), finally leading to a disclaimer (Van Dijk, 1992) ("I don't know how to explain it, I think it's ok, but...") that anticipates an anti-immigrant claim through the 
container-metaphor ("if we are already two thousand inhabitants here, there can't be four"). We referred to this metaphor in extract 1 , related to the idea that the hosting country has a limited capacity to receive foreigners. However, whilst in extract 1 this metaphor qualified an explicitly racist claim of "cleaning-up" the country, in extract 8 the nativist demand of expulsion manifests by implication (Durrheim et al., 2008). This confirms the key role of background nativist assumptions in the metonymical display of xeno-racist claims. The argument according to which countries have maximum capacities semantically implies that no more people can be "put into" them. Translated into immigration language, the argument is that no more immigrants must come, even if this claim is rhetorically formulated as a matter of spatial availability that protects the speaker from imputations of xeno-racist stakes. Moreover, in this ideological frame the metaphor of an overloaded container (i.e. excess of people) makes consequentially logic the implied idea of emptying as a socially selective process (i.e. removing them-foreigners, not us-natives who belong here and were here before). In sum, the account in extract 8 embeds insecurity in the frame of economic scarcity and related social problems "here" in a way that warrants nativist claims against the presence of foreigners, by mobilizing the xeno-racist spread belief that immigrants' presence aggravates current structural problems in Spain (Colectivo IOÉ, 2012). 
However, one must not conclude that nativist positions sooner or later end up demanding immigrants' expulsion. As Wetherell and Potter (1992) have argued, also liberal claims may be formulated to provoke discriminatory effects. Extract 9 precisely illustrates this point. Here, two young men reflect on what should be done to reduce urban insecurity -a different sort of narrative 'conclusion'. The extract was preceded by a large explanation about how city-changes have supposed the massive coming of immigrants who are socially disadvantaged and commit misdemeanors for necessity. In the extract, the interviewees call for inclusive social policies and "raising awareness", "giving opportunities" and "jobs" to "these people" so they "don't need" to fall into crime. Expulsion does not fit into these progressive measures that explicitly exclude the police. The rationale sustaining this position nevertheless relies on two interrelated assumptions that connect these liberal claims to illiberal nativist effects (Augoustinos and Every, 2007). First, the speakers reasonably equate immigration to poverty and social disadvantage, but in doing so they discursively construct for themselves (as natives) the advantaged position of care-givers. This establishes a paternalistic relationship of dependence between natives and immigrants enshrined in the broader implied logics of assistance-giving. Regardless of whatever good intentions the speakers may have, their turn-taking discourse of social needs collaborately builds their political profile as liberals as much as their structural emplacement as White, 
class-positioned locals delivering resources. Second, and crucially, the discourse of needs is grounded on the unquestioned presupposition (Van Dijk, 1993) that those who cause insecurity are actually the immigrants, who are un-problematically treated as the crimesubjects. In fact, the (liberal) demand of giving jobs and opportunities to immigrants is the consequence of a previous (illiberal) naturalization of the latter as the people who commit misdemeanors. The argument that immigrants commit misdemeanors because they "need to" is an 'explicative' justification that unfortunately builds on the prior criminalization of the immigrant as the one and only delinquent: that insecurity is created by an (over)generalized immigrant Other is presupposed and is never discussed (Van Dijk, 1984). In this discursive context, interviewee 2's depiction of immigration as "increasing" and "unavoidable" further intensifies this generalized naturalization of the immigrant as the cause of urban insecurity.

\section{Conclusion}

Fear of crime has become a social topic that refracts culturally related debates embedded in the imaginary of crime (Garland, 2001; Jackson, 2004). In this article we have shown that immigration is one of these debates and that xeno-racist opinions, assumptions and claims are channelled through everyday accounts about urban insecurity as a crime-related 
experience. In so doing, we have contributed a social-psychological discursive approach that illustrates how xeno-racist views and demands are metonymically articulated through a language of criminal and deviant practices. When asked about urban insecurity (i.e. the explicit topic), the subject position of a threatening Other within a canonical fear of crime narrative is pervasively constructed in xeno-racial terms (i.e. being immigration the implicit topic). More specifically, the delinquent-immigrant discourse is worked through in talk at three metonymical levels. First, the question for urban insecurity triggers descriptions of criminal or deviant actions that initially stand for the identity of their perpetrators, which is usually submerged in the conversational background until it surfaces at some point as a xeno-racial character in the delinquent-like narrative. Thereby, the insecurity frame affords the citizen a set of discursive resources to depict the immigrant in a negative way, as well as to demand and warrant his/her physical expulsion, not by virtue of his/her xeno-racial identity but appealing to his/her alleged unacceptable acts. Second, this metonymic formulation is usually managed in discourse through a set of deracialization strategies that rhetorically displace rejection of the out-group towards culturally contiguous languages, such as incivilities, multiculturalism and socioeconomic disadvantage (see also Van Dijk, 1984, 1987, 1992a). Accounts of vandalism, conflicts inexorably tied to cultural diversity and robbing as a need discursively naturalize the identity of their (immigrant) protagonists 
as delinquents and trouble-makers. Paradoxically, although reproducing the xeno-racist cultural imaginary through the insecurity frame, these two first levels of metonymic discourse indicate that race and immigration are still sensitive topics in the public opinion, and that a certain sense of cultural resistance to public expression of xeno-racist appraisals lives on (otherwise straightforward explicit rejection would be the norm, and not the exception). It must be noted here that metonymic displacement is effective to protect the self from accusations of being a racist because semantic contiguity operates within the cultural ideo-logics of rejection implicit in the shared background knowledge of speaker and hearer. It is mainly for this reason that xeno-racist metonymies (e.g. the "culturally different" trouble-maker living "down-town") can effectively participate as more concealed ideological resources in the semiotic fabric that sustains xeno-racism as a symbolic field of power relations.

The third level of metonymic substitution implies the use of geographical language ("here", "there", "coming", "going home") to construct the negative identity of immigrants as an out-group that is essentially transgressive for being territorially out-of-place, and not for being xeno-racially different. Xeno-racism is in part a locational ideology based on the nativist common assumption according to which natives must have privileges and priorities compared to immigrants, because the former belong to the place whereas the latter lack this 
place-identity. As Billig (1991) has argued, common sense is sediment of naturalized ideological beliefs that have culturally become unquestionable and work in discourse as self-evident arguments. That 'the ones who live here have priority' is one of such assumptions, whose main ideological effect is the legitimation of the higher status and dominance of one group of people over the other. How the discursive circulation of this nativist pressuposition is relevant for justifying exclusionary practices and an unjust arrangement of the social order should be clear from our analysis. We have shown particularly how this nativist truism underlies and self-evidently grounds people's calls for direct expulsion of immigrants, explicit demands of border control and claims for limiting foreigners' presence "here", when what is explicitly at stake is the issue of urban insecurity. More revealingly, native supremacy, i.e. the native-centred status quo feeding-back xenoracist ideology, is underpinned by related self-attributed entitlements, such as the right to define the Other as different, to supervise the boundaries of difference and to claim for a privileged social and territorial position by virtue of in-group, nation-related placebelonging.

The exploration of urban insecurity as a discursive arena that channels the ideological workings of nativist assumptions confirms the versatility, perseverance and high resistance of xeno-racism today, even when the crisis in Spain has inverted the (until 
year 2012) incremental tendency to receive foreign people (Martínez, 2013). In analytical and theoretical terms, it allows deepening more into the difficult task of pinpointing how xeno-racism works through apparently non-xeno-racist talk. This requires examining the submerged ways of doing xeno-racism via figurative languages and non-ethnic topics of discourse, the ideological effects of which stem from the yet seldom explored interface between foreground talk and background cultural knowledge.

\section{Notes}

For other studies in everyday ethnic prejudice in Barcelona, see López Ó and Aharchi N (2012). Discursos sobre la inmigración rrom (gitana) rumana en Barcelona. Estudio de la representación del "conflicto vecinal" y los trabajos marginales a partir de El País, La Vanguardia y El Periódico de Catalunya (2006-2011). Discurso \& Sociedad 6(3): 543-590, and Unamuno V and Codó E (2006) Categorizar a través del habla: la construcción interactiva de la extranjeridad. Discurso \& Sociedad 1(1): 116-147.

\section{Funding acknowledgement}

This work was supported by the Spanish Ministry of Science and Technology (Grant PSI2010-21214-C02-02). 


\section{References}

Augoustinos M and Every D (2007) The language of "race" and prejudice: A discourse of denial, reason and liberal-practical politics. Journal of Language and Social Psychology 26(2): 123-141.

Billig M (1991) Ideology and opinions. London: Sage.

Billig M, Condor S, Edwards D, Gane M, Middleton D and Radley A (1988) Ideological dilemmas. A social psychology of everyday thinking. London: Sage.

Carro D, Valera S and Vidal T (2010) Perceived insecurity in the public space: personal, social and environmental variables. Quality and Quantity 44: 303-314.

Charteris-Black J (2006) Britain as container: Immigration metaphors in the 2005 election campaign. Discourse \& Society 17(5): 563-581.

Colectivo IOÉ (2005) Ciudadanos o intrusos: La opinión pública española antes los inmigrantes. Papeles de Economía Española 104: 194-209.

Colectivo IOÉ (2012) Impactos de la crisis sobre la población inmigrante. Report for the International Migration Office.

Del-Teso-Craviotto M (2009) Racism and xenophobia in immigrants' discourse: The case of Argentines in Spain. Discourse \& Society 20(5): 571-592.

Di Masso A (2007) Rhetorical uses of public space: The discursive organization of a space in conflict. Athenea Digital 11:1-22. 
Di Masso A (2012) Grounding citizenship: Toward a Political Psychology of public space. Political Psychology 33(1): 123-143.

Dixon J, Foster D, Durrheim K and Wilbraham L (1994) Discourse and the politics of space in South Africa: The 'squatter crisis'. Discourse \& Society 5(3): 277-296.

Dixon J, Levine M and McAuley R (2006) Locating impropriety: Street drinking, moral order, and the ideological dilemma of public space. Political Psychology 27(2): 187206.

Durrheim K and Dixon J (2001) The role of place and metaphor in racial exclusion: SouthAfrican beaches as sites of shifting racialization. Ethnic \& Racial Studies 24(3): 433450.

Durrheim K, Hook D and Riggs D (2008) Race and racism. In: Fox D, Prilleltensky I and Austin S (eds) Critical Psychology: An introduction. London: Sage, pp.197-214.

Edwards D and Potter J (1992) Discursive Psychology. London: Sage.

Fekete L (2009) A suitable enemy. Racism, migration and islamophobia in Europe. New York: Pluto Press.

García E, Díez J, Pérez M, Benítez M \& Cerezo A (2010) Evolución de la delincuencia en España: Análisis longitudinal con encuestas de victimización. Revista Española de Investigación Criminológica 8: 1-27. 
Garland D (2001) Culture of control: Crime and social order in contemporary society. Chicago: Chicago University Press.

Gergen K (1989) Warranting voice and the elaboration of the self. In: Shotter J and Gergen K (eds) Texts of Identity. London: Sage, pp.70-81.

Goffman E (1981) Forms of talk. Oxford: Blackwell.

Gotsbachner E (2001) Xenophobic normality: The discriminatory impact of habitualized discourse dynamics. Discourse \& Society 12(6): 729-759.

Hollway W and Jefferson T (2000) Doing qualitative research differently. London: Sage.

Jackson J (2004) Experience and expression. Social and cultural significance in the fear of crime. British Journal of Criminology 44: 946-966.

Jefferson G (1984) Transcript notation. In: Atkinson J and Heritage J (eds) Structures of social action: Studies in conversation analysis. Cambridge: Cambridge University Press, pp.ix-xvi.

Keith M (1993) Race, riots and policing: Lore and disorder in a multi-racist society. London: UCL Press.

Lee M (2007) Inventing fear of crime. New York: Routledge.

Martínez M (ed) (2013) Discourses on immigration in times of economic crises. A critical perspective. Newcastle: Cambridge Scholars Publishing. 
Marzorati R (2011) Conflictos en el espacio público y construcción de la alteridad: Una comparación entre barrios en Milán y Barcelona. Architecture, City and Environment 6(17): 293-316.

Miceli R, Roccato M and Rosato R (2004) Fear of crime in Italy. Spread and determinants. Environment \& Behavior 36(6): 776-789.

Miller J (1994) Immigration, the press and the new racism. Media Studies Journal 8: 19-28.

Pickett J, Chiricos T, Golden K and Gertz M (2012) Reconsidering the Relationship Between Perceived Neighborhood Racial Composition and Whites' Perceptions of Victimization Risk: Do Racial Stereotypes Matter? Criminology 50(1): 145-186.

Potter J (1996) Representing reality: Discourse, rhetoric and social construction. London: Sage.

Potter J and Wetherell M (1987) Discourse and Social Psychology. London: Sage.

Quillian L and Pager D (2010) Estimating Risk: Stereotype Amplification and the Perceived Risk of Criminal Victimization. Social Psychology Quarterly 73(1): 79-104.

Reeves F (1983) British racial discourse: A study of British political discourse about race and race-related matters. Cambridge, UK: Cambridge University Press.

Santa Ana O (1999) 'Like an animal I was treated': Anti-immigrant metaphor in US public discourse. Discourse \& Society 10(2): 191-224. 
Schegloff E (1972) Notes on conversational practice: formulating place. In: Sudnow D (ed), Studies in social interaction. Glencoe, IL: Free Press, pp. 75-119.

Sercombe H (1995) The face of the criminal is aboriginal. Journal of Australian Studies 43: 76-94.

Sivanandan A (2001) Poverty is the New Black. Race \& Class 43(2): 1-5.

Stewart C, Pitts M and Osborne H (2010) Mediated intergroup conflict: The discursive construction of "Illegal immigrants" in a Regional U.S. Newspaper. Journal of Language and Social Psychology 30(1): 8-27.

Taguieff P (1987) The force of prejudice. On racism and its doubles. Minneapolis: Minnesota University Press.

Taras R (2012) Xenophobia and islamophobia in Europe. Edinburgh: Edinburgh University Press.

Taylor S (2005) Identity trouble and opportunity in women's narratives of residence. Auto/Biography 13: 249-265.

Taylor S and Wetherell M (1999) A suitable time and place: Speakers' use of 'time' to do discursive work in narratives of nation and personal life. Time \& Society 8: 39-58.

Thompson JB (1990) Ideology and modern culture. Stanford, CA: Stanford University Press. 
Tulloch J, Lupton D, Blood W, Tulloch M, Jennett C and Enders M (1998) Fear of crime. Canberra: Centre for Cultural Risk Research for the NCAVAC Unit, AttorneyGeneral's Department.

Van Dijk T (1984) Prejudice in discourse: An analysis of ethnic prejudice in cognition and conversation. Amsterdam/Philadelphia: John Benjamins Publishing.

Van Dijk T (1987) Communicating racism: Ethnic prejudice in thought and talk. Newbury Park, CA: Sage.

Van Dijk T (1992a) Racism, elites and conversation. Atlantis. Revista de la Asociación española de estudios anglo-americanos 14(1/2): 201-257.

Van Dijk T (1992b) Discourse and the denial of racism. Discourse \& Society 3(1): 87-118.

Van Dijk T (1993) Analyzing racism through discourse analysis: Some methodological reflections. In: Stanfield J (ed) Race and ethnicity in research methods. Newbury Park, CA: Sage, pp.92-134.

Van San M (2004) Des quartiers de mauvaise réputation. L'image de la criminalité dans deux cartiers en Belgique. Déviance et Societé 28(2): 211-231.

Wallwork J and Dixon J (2004) Foxes, green fields and Britishness: On the rhetorical construction of place and national identity. British Journal of Social Psychology 43: 2139. 
Welch K (2007) Black criminal stereotypes and racial profiling. Journal of Contemporary Criminal Justice 23(3): 276-288.

Wetherell M (1998) Positioning and interpretative repertoires: Conversation analysis and Post-structuralism in dialogue. Discourse \& Society 9(3): 387-412.

Wetherell M and Potter J (1992) Mapping the language of racism. London: Harvester Wheatsheaf.

\section{Appendix: Original extracts}

(1) Pues que hay inseguridad, la verdad. Hay mucho (.) Yo por lo menos lo que veo por aquí, mucho musulmán que va (.) moro o dile como quieras, que tienen siempre la mano en el bolsillo de los demás. Y además los ves, ¿eh? (...) Han entrado más de los que tendrían que entrar, eso por supuesto. Porque de chorizos ya teníamos nosotros y no más falta que los incrementemos. Pero es que aparte de eso, como que ha entrado todo, y digo todo no todos, todo. Pues claro, si no ha habido un poco de limpieza (.) nos ha entrado lo bueno y de lo malo muchísimo, que es lo primero que se va de un país.

(2) ...un home que se li veia que no era normal, em va aturar i em feia preguntes tontes, no? (...) hi ha una infinitat de coses que promouen (.) promouen que ha vingut una gent estranya i ha vingut només que per això, per fer mal, aquesta és la meva opinió (...) Perquè hi han barris cap al centru, que allà sí, allà és, és, és el "novamás" allò, de gent, de mala gent, oi? (...) Pues miri, jo crec que la mesura més important seria controlar les fronteres (...) controlar, crec que no ho fan, perquè aquí ve tothom, i s'està aquí sense (.) sense legalitzar (...) tothom ve aquí descaradament, però descaradament, eh?, descaradament, sobretot estrangers, estrangers.

(3) Entrevistado: Yo personalmente sí ((me siento seguro)), pero veo gente mayor que no se siente segura. Les han dado tirones y cosas (.) se ceban en la gente más débil (...) Entrevistador: ¿Qué se podría hacer para ayudar en este aspecto? 
Entrevistado: Aumentar más policía, echar a la gente que haga delitos y que no tenga papeles.

(4) Aquí ((la seguridad)) está fatal. Más en este sector. Está fatal. Peleas, se mean por todos los sitios, si pueden te atracan (.) lo que quieras. Luego aquí la discoteca de aquí, salen a las seis de la mañana, ¿eh?, y aquí no hay quien pase, la policía no hace nada (...) y la suciedad, está sucio, aquí salen y se mean por todos lados, tiran (...) aparte hubo aquí un sector de gente que las cadenas te las estiraban, a mí el mes de septiembre me la estiraron aquí en la calle San Pablo (...) me la estiraron una chica (.) a otro vi a una persona que era negra, no sé que sea eso.

(5) Pues sí, que hay mucha inseguridad y no voy a decir que la policía no hace nada. Venden droga aquí al lado. Hay cada dos por tres robos, cada dos por tres follones, cada dos por tres líos (...) siempre está asqueroso, la gente, la gente que nos han traído aquí, esto es un gueto, la gente que ha venido, que será pos su cultura, por lo que sea, pues están acostumbradas que les sobre esto, lo tiran. La basura no la tiran dentro, la tiran fuera, pero eso son tonterías, que muchas muchas hacen una grande, y el barrio es una mierda.

(6) Entrevistado: Mi opinión ((sobre la inseguridad))? Bueno, hay mucho vandalismo. Vandalismo, o sea encima trabajo en ((compañía de gas)) y tengo que visitor domicilios y te aseguro que la gente está cagada (...) El distrito de aquí esto es terrible (...) Alucino con las caras que te mira la gante inmigrantes y todo, porque la gente que vive aquí, que es de aquí de toda la vida, pasa mucho miedo, mucho, mucho, mucho, tú se lo ves. La gente mayor está indefensa, ante esto.

Entrevistador: Para finalizar, ¿qué tipo de medidas crees que...?

Entrevistado: Bueno, el que no tenga papeles a su casa, así de claro (.) Hacer aquí una batida superheavy y que pete, que pete, pero esto se tiene que limpiarse, o sea, esto no puede quedar así, y irá a más (.) más crisis, más vandalismo.

(7) Barcelona es muy compleja multiculturalmente, entonces creo que esa complejidad hay que (.) hay que gestionarla más activamente (...) para empezar, se deben respetar las diferentes culturas y religiones que en Barcelona hay, se hablan 167 lenguas, mínimo, entonces esto ya genera una complejidad en un espacio tan compacto como Barcelona, entonces yo creo que genera conflictos, claro que genera conflictos, porque la gente tiene diferentes formas de vivir en un espacio y, bueno, en su momento se le abrió las puertas a esta gente y ahora, pues creo que es una forma parte de la realidad de Barcelona (...) De momento ni me han 
robado ni he tenido ningún problema, entonces, y me gusta esta diversidad, hay gente que la ve como inseguridad.

(8) No estamos seguros (...) realmente no hay justicia, de todo, las familias, la gente (.) que está en paro, la gente que no tiene trabajo (...) te encuentras que no tienes trabajo, que (.) que estás mal, que debes una hipoteca que no puedes pagar y que, bueno, todo influye en todo (...) yo no estoy en contra de nadie, ¿me entiendes? Yo el que está aquí, bienvenido y, no sé cómo explicarte, y lo veo bien, pero vamos lo que no veo bien es que si aquí somos dos mil habitantes no puede haber cuatro, cuatro mil habitantes cuando no se puede. Se tendría que limitar, limitar a (.) para mí sería limitar y decir "bueno, tanta gente hay, pues tanta gente quedamos", y ya está.

(9) Entrevistado 1: Sí, no sé, seria més fácil dona'ls-hi oportunitats en aquesta gent perquè no tingui la necessitat de...

Entrevistado 2: ... és més lent conscienciar la población que no pas dictar el que s'ha de fer, no? Conscienciar és més lent i requereix un moviment pel del poble i entendre (.) asumir, asumir que la immigració va a més i que no es pot evitar, no es pot evitar...

Entrevistado 1: ... i que hi hem de conviure, i si a aquesta gent se'ls dóna una oportunitat, si se'ls dóna feina no tindran la necessitat, segurament, de delinquir, suposo que s'haurien de fer més polítiques encaminades cap aquí...

Entrevistado 2: ... conscienciar, conscienciar...

Entrevistado 1: ... dona'ls-hi possibilitats i oportunitats i no pas censurar a través de la policia. 